\title{
DEVELOPING STUDENT VOCABULARY WORKSHEET BY USING AFFIXES
}

\author{
Intan Pradita \\ Nizamudin Sadiq \\ Islamic University of Indonesia
}

\begin{abstract}
This paper aims at describing the stages of developing vocabulary worksheet by using affixes by adopting the process of the same development research of Wutsqo. The stages of vocabulary worksheet development involved the needs analysis, the making of the vocabulary worksheet, the validation process by the reviewer, the make up of the first design based on the feedback by the reviewer, and the try out. the object of this study was the students of Grammar for English Teacher class of the academic year 2014/2015. The instruments of this study were pre-test as the initial needs analysis of the students capability of vocabulary stock that they had. The second instrument was the previous research data that was conducted by the researchers to identify how necessary to develop an effective vocabulary learning. The third instrument were three two of questionaires. The first one was for the reviewer to validate the first design of the worksheet and to ask for the feedback, and the second one was for the students in order to identify their personal impression towards the worksheet. The results of this study are; 1) Based on the assessment validator can be concluded that the aspect of validity has met the criteria development vocabualry student worksheet to learn the material additive that has been prepared to have a very good quality, 2) Based on the recommendation of experts and providers of materials, practicality aspect has fulfilled the minimum criteria with certain notes on 21st century learning, 3) The results of the pre-test and post-test student learning augmentation material by using SVW has met the minimum criteria of improvement.
\end{abstract}

Keywords: students vocabulary worksheet, research and development, affixation, morphology

\section{Introduction}

Vocabulary is an important element in second language acquisition. This study highlights the importance of English vocabulary learning as a 
supported factor of learning English grammar. The previous study conducted by the researcher described the needs analysis of English learning by the students of Islamic University of Indonesia, whom the samples were the students of the department of Architecture, Pharmacy, and Psychology (Sadiq: 2012).

The result of the study described two things; 1 ) the identification of weaknesses that the students have in relation with their English learning, and 2) their wishlist of improving proficiency. The result has proved a commonsense of English learning in Indonesia that grammar becomes the most concerned feature of English proficiency. Some of the respondents even described that grammar was their nightmare for any kind of tests. The researcher has attempted to develop a workboook of grammar entitled Formula 33 as a solution for English grammar in a more hands on worksheet compilation.

The second concern of English proficiency is vocabulary mastery. The students also add that the lack of vocabularies makes them loose the meaning of parts of the sentence in certain test. Regarding the wishlist of vocabulary mastery problem, the students tend to wish that they will have a lot of vocabularies which could be implemented in the translation skills and speaking skills.

Harmer (1991) makes an analogy if it is a piece of body, the structure is bones that make up the framework, while the vocabulary is the meat that makes the body has a form. Thus one would not be able to communicate in the target language if the mastery of vocabulary is inadequate.

Thus, the vocabulary would be a less important part of mastering grammar. However, the strategy pengusaaan and learning vocabulary used previously carried out by the method of memorizing. This proved to be effective to improve the mastery of vocabulary. Therefore a more effective breakthrough to improve student mastery of vocabulary in a significant time span. In a research report, Susanti (2002) suggests that teachers in the classroom teaching should be able to create methods and techniques of English vocabulary learning fun for the students so that the students would be actively involved in learning the English vocabulary.

In general, there are three levels in vocabulary, which is unknown, acquinted, and established (2003: 43). Unknown student in the stages really do not know the meaning of a word. While in the stages acquinted, students familiar with the word, and was able to guess the meaning of the word. For the highest stage, that is established, students not only know the meaning of the word, but also capable of using the word correctly. In the classroom observation ever made, students are likely still in the stages of unknown and some of them acquinted (Sadiq, 2012). This research will be directed so that students can reach the established stages. 
When summarized, basic English vocabulary totaled 100 thousand's. The 100 thousand, 10 thousand of them belonging to the vocabulary that is often used. The number of 10 thousand is standard in the world for those who are learning English. That is, if an English learner has mastered 10 thousand words, then he was able to communicate in English is active both in writing and orally. However, this amount is still felt quite heavy to be mastered. Therefore, for high school graduates who entered in the novice category, which must be mastered enough vocabulary of 4,000 words. That is why the curriculum in Indonesia stated that the high school or high school graduates must master the vocabulary is very often used where the amount is 4,000 vocabulary.

However, when the test was held in the early half of vocabulary Universities (Sadiq, 2012), only a small portion of high school graduates who can master the 4000 words. In general, the amount of vocabulary they control only about 400 words. Consequently, with the acquisition of 400 vocabulary is difficult for high school graduates to attend lectures English at a higher level. In fact, when compared with the control children's vocabulary in English-speaking countries mothers, children aged 5 to 6 years have a vocabulary of operational between 2,500 and 5,000 words (Beck and McKeown, 1991 in Wren).

That is why, the results need analysis with empirical facts roped mutual rigging. Thus, the question arises about the method of vocabulary. One way that is often suggested is to memorize ten words a day. Logically if one day an English language learner to memorize 10 words, then within 2 days disa was able to memorize 20 words. And so on, in the year in question was able to memorize 3650 words.

Based on empirical experience of researchers, the method proved ineffective. This is due to the limited ability to memorize someone. During one year of memorizing vocabulary can be memorized only 10 said the words memorized in the last day. Meanwhile, the vocabulary is rather remembering numbers are also about 10 the memorized vocabulary to 364. Day of vocabulary memorized since day one to day 363 lost all from memory because most of the vocabulary can not be remembered or forgotten.

One way to improve the effectiveness of the vocabulary is to use teaching materials. Teaching materials to facilitate the students for the purposes of one of them is the Student's Worksheet. Student's worksheet can be in the form of sheets containing about problems or exercises that should be done by students with faculty guidance to master the concepts of a subject matter, to facilitate students in learning the material and to train the process of thought in understanding the particular material.

Students will be designed worksheet is the worksheet-based additive. Affixes been one of its advantages is the additive can assist students in 
learning words that are rarely known by connecting words that are rarely known with words or prefixes and suffixes commonly used (Nation, 1990 in Nakayama, 2008). Bauer and the Nation (in Nakayama, 2008) explains that because of the similarity between the first language and second language then when learners have knowledge of prefixes and knowing the basic words of a word, the learners can guess and use the word jadiannya (derivative words). The suffix as part of the system words give learners of English how to improve vocabulary (Nation, 2013)

In addition, affix been shown to be effective in the development of the language learner's vocabulary. Results of research conducted by Dradjadlaksana in 1997 showed that mastery of the vocabulary of English learners increased by way of introduction to the workings of the particle. Through this understanding, it is easier to transform classroom learning words and function words than the rote memorization. Therefore, this proposal seeks to develop students vocabulary worksheet (SVW).

This research is aimed at developing a students' vocabulary worksheet based on affixation. The formulation of the problems are on how to develop student vocabulary worksheet based on affixation process, and how effective the student vocabulary worksheet is to improve the students' vocabulary mastery.

\section{Vocabularies: roots and affixes}

As mentioned previously, that the ability of non-English education student smallest is the sensitivity of the grammar. Pattern appropriate learning for students is by strengthening element morphosyntax (morphology and syntax). This is because the motivation of learners is to master the English language, not to decipher the phenomenon of the English language. Aitchinson (2003: 37) explains that there are three essential components of a hierarchical to master the grammar of a language, ie phonology (including phonetics), syntax (including morphology), and semantics. Language learning will be more effective with a description of the pattern (pattern). As an example of the relationship between morpheme, the relation between vowel, or relationships between words in a field of meaning.

Language learning in syntactic level can not be separated from the mastery of vocabulary. English language learners are no longer familiar with the methods of memorization, because the end result will tend to be quantitative. They have a hundred stores vocabulary, but was unable to use it. It should be understood that the indicators of achievement of learning vocabulary is enriched vocabulary and the ability to use it (Pikulski and Shane, 2004: 1).

Vocabularies in The American Heritage Dictionary in Pikulski and Shane (2004: 2) is defined as a collection of words used, understood, or delivered by some person or group. In the development of its functions, there are several kinds of vocabulary. According Antonacci and Catherine (2012: 83) 
language teachers there that teach vocabulary that focus on the introduction of new words (sight-word vocabularies), there is also a form of vocabulary to assess understanding of the meaning (meaning vocabularies), and vocabulary which refers to specific terminology of a field (academic vocabularies).

While Pikulski and Shane (2004: 2) gives the definition of a more comprehensive vocabulary through the images below:

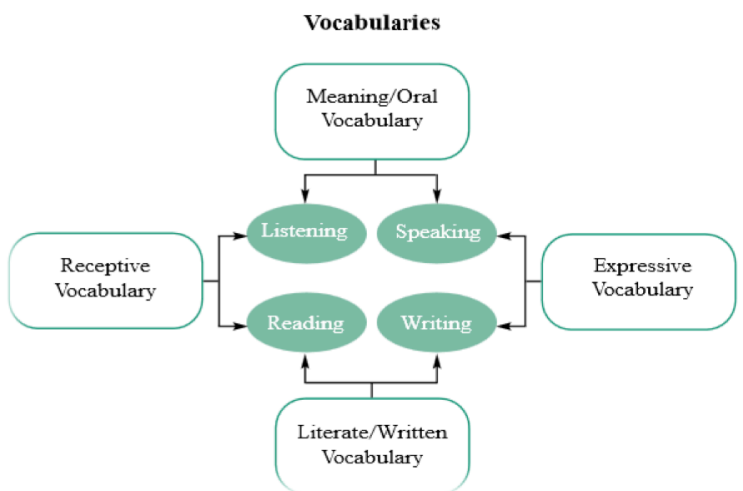

According to the stages of acquisition, vocabulary divided into two, namely the literal meaning vcabulary and vocabulary. Vocabulary oral / (meaning vocabulary) was first obtained come from everyday language and mother tongue. The next stage is the vocabulary literal (literal vocabulary). While the manner of its acquisition, vocabulary can be expressive and receptive. Receptive vocabulary was obtained after a hearing or reading, while vocabulary expressive of their use through writing and speech.

The research focuses on the receptive and expressive vocabulary, because the formation of another vocabulary is psycholinguistic research approach. The increase in the acquisition and use of English vocabulary can be supported in several ways (Mikulski and Shane, 2004: 8), namely: 1. Using the read-aloud instructions. 2. Provide easily understandable instructions for the meaning of the word and the word itself. 3 . Systematically teach learners about the use of prefixes suffixes and root words. 4. To teach about the relationship with reading and spelling instruction vocabulary instruction. 5 . Teach the efekstid, efficient and realistic about the use of a dictionary and thesaurus. 6. Teach, give examples, and support the production of a strategic learning applications. 7. Supports the habit of reading as a whole, and 8. Creating a pleasant atmosphere for learning vocabulary.

\section{Affixation}

Many researchers who support the use of the suffix (affix) for the development of vocabulary (Nation, 1990; Bauer \& Nation, 1993 in Nakayama). Schmitt research results (at Nakayama 2008) showed that $69 \%$ 
of learners of English in Japan stating that memperlajari by analyzing prefix word and the word is very useful basis (helpfull).

The suffix is one type of a language morphological processes involving free and bound morpheme elements to form new words. With the additive, the vocabulary of a language will be richer. As mentioned in a study conducted by Dradjadlaksana (1997) that the learner's vocabulary is increasing with the passage of the introduction of the use of augmentation. Affixes or affixation according Wijana (2011: 63) is the process of adding affixes to form the basis of an initial or morpheme. The addition can be placed at the beginning (prefix / prefix), in the middle (insertion / infix), at the end (suffix / suffix), konfiks, and the combined affixes.

Basically the process of formation of words (word formation rules) begins with the introduction of two kinds of morpheme, namely the free morpheme and morpheme. Carstairs and McCarthy (2002: 18) describes that the free morpheme is a morpheme that can stand on its own, while the morpheme is tied / dependent on the other morpheme. For example, the word adjective readable form, is formed of two morpheme is read and Able. Read morpheme is a free morpheme, because without being followed Able she still has meaning and word class position, namely as a noun. While -able is bound morpheme. Because when standing alone, morpheme has no meaning and word class. Morpheme in certain circumstances can become very attached to morphemes free. For example, the morpheme buckle-, cran, in buckleberry and cranberry. Formation of such words is the one who often confuse students. Most of them come to the university with memorizing vocabulary, so when it encounters a change morpheme become confused.

The position of free morpheme by Carstairs and McCarthy (2002: 20) then becomes the core of a word or word basis. The question that needs further reviews are usability affixation in the formation of a word. In terms of morphology, there are two types of morpheme derived from affixation process, ie inflection and derivation. Both types of morpheme is very important in the process of enriching the vocabulary of English language learners. Most English words is formed by a combination of elements, namely the prefix and suffix morphemics, with the basic words. If the learner understand the process of this combination, they will have one of the strong points of language acquisition through the development of vocabulary (Anderson and Freebody in Pikunski and Shane, 2004: 6)

In the development of the latest research, there are some guidelines teaching uses prefixes, suffixes, root words and their implementation (Templeton in Pikulski and Shine, 2004: 6) For learners intermediate level, they will explore forms of prefixes and improve the ability to identify the suffix, and how usefulness both to the basic words. Examples govern (verb) + -ment $=$ government (noun). Morpheme derivation is changing class 
morpheme morpheme word when added to another (O'Grady, 2001: 32). As an example of a free morpheme serious form of the adjective, when added morpheme -ly then will turn his class into adverbs, ie seriously. Another example is a free morpheme forgive the form of the verb, if added -en morpheme will turn his class into adjectives, namely Forgiven. Whereas, inflectional morpheme will not change the class, he said. It will only change the function, for example, be plural or a verb now and the past.

There are several advantages to study particle-additive commonly used. First, when students are already familiar with the pronunciation / phonation of a prefix, suffix or root of the word they have had a good startup capital to ring the new words that perhaps they do not know. For example, a student will have the ability to mention the word, for example, Transcontinental easier because -trans is a group of words common / familiar / frequently used by people. Second, students can more easily determine the meaning if they already know the meaning of an additive such as anti(against) the antiwar word. Third, students will realize that the knowledge of the particle will be very useful when spelling (spelling). Because some additive has several variations in spelling (ANT, ent-), knowing the particle will assist in spelling words eg anterior.

\section{The development of vocabulary learning}

In the process, starting with the method of learning vocabulary Discourse-based language teaching (1988) which became the forerunner of Communicative Language Teaching, followed by the phrase lexical approach (Carter \& Mc Carty, 1988), lexical approach (Lewis, 1993- 997) that Popular with rote method, then lexical syllabus (Sinclair \& Renauf, 1998, and Willis 1990) which is a morphological approach to word formation. In addition, the latest form of teaching vocabulary also exist, which is in the format of the corpus by modern technology.

The first stage is associated to the competence established vocabulary for carrying the vocabulary in a text containing a certain context. While the phrase lexical approach phases associated to unknown vocabulary and acquinted as well as accommodate the introduction of vocabulary enrichment. Lexical approach is also famous phrase because it accommodates learners base- tingka medium. Right morphological approach used for unknown stage so that students are more familiar with specific vocabulary. Then for enrichment to acquinted stages, students will be introduced to the reasoning according affixes meaning attached to the base word. Thus, the approach of vocabulary in the form of lexical approach in the form of rote, is no longer effective, because students will have the risk to forget. 


\section{The Learning Strategies Grand-design}

According to the results of classroom observations, students since high school tend to be taught by rote memorization of vocabulary and understand the word. They were then asked to make sentences out of words. Nevertheless, given vocabulary tends to be forgotten just because the user only when it is discussed in the classroom. Students are not accustomed to using a particular vocabulary for his production skills are not honed to maximum. In other words, in high school, students tend to just introduced specific vocabulary, but not diperkaya- not used continuously went on and not categorized in a certain context.

This refers to the development of research on lexical pattern phrase approach to introduce a variety of words in the coverage categories. Then introduced how to change the word class through penedekatan morphology, namely affixes. So with only one word to know the basic course, students will further enrich the vocabulary to 3-5 words. For example, for unknown stages, students are introduced basic economy of meaningful word economy, belongs to a class noun. Then, with the understanding lexical phrases in the form of affixes suffix -ics, -cal, -ies, -itrian, -ize, -cally, the student has more bank said, namely economics (economics-grade noun), economical (hematclass adjective), economies (economy-class noun), economitiran (economicclass mathematician noun), economize (berhemat- class of verbs), and economically (with hemat- class of adverbs). By mastering 6 word-based economy, then the student is getting a lot of his word bank (unknown phase have been met).

Then to familiarize with the meaning of words, then by characterizing the meaning of affixes (that ends -cal tend to form adjectives, which ends in -ist, $-y$, and -ies tends to be a noun; experts / specialists, noun formed from the verb, and pluralism), then the student will easily find a pattern of meaning as the word is already used in a large text. Students do not always have to memorize the meaning, but was able to guess the meaning of words through her bound morpheme. Familiarity vocabulary is shown by the indicator's ability to guess the meaning of the word. So the vocabulary becomes easier.

Referring to the discussion above, the research standpoint this development is to maximize vocabulary with vocabulary enrichment and the use of vocabulary. Thus, this development research abandon the tradition of learning lexical approach and accommodate the needs of learners basic level. 
the design of learning strategies is illustrated in the figure below:
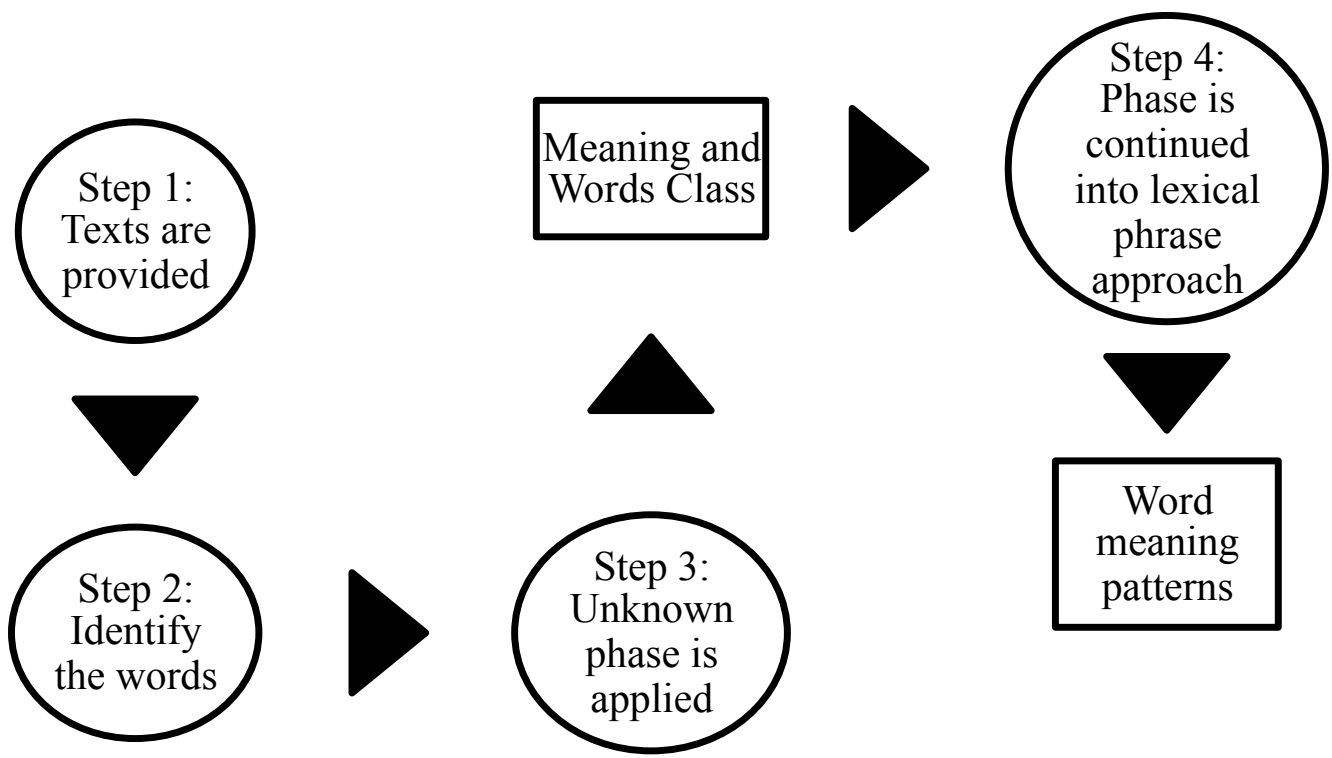

\section{Research Method}

The research was conducted at the campus of the Islamic University of Indonesia, in Jalan Kaliurang KM 14.5, Besi, Sleman, Yogyakarta 55584. This type of research is the development of research that is intended to develop a students vocabulary worksheet based on affixation. The study population was all students of English Education, Faculty of Psychology and Social Sciences Culture held in the second semester of academic year 2013-2014 at UII integrated campus. The samples were the students of Grammar for English Teachers class (henceforth GET). It was selected by purposive sampling technique. The research instruments used in this study were (1) sheet of assessment of a team of experts (2) The student questionnaire responses to student learning vocabulary worksheet, and (3) test to reveal the mastery of vocabulary.

\section{The research design}

The design of this study using the stages of development compiled by Wutsqo (2010) with three stages, namely the preparatory stage, the stage of development of the worksheet, and the final stage. At each stage of the implementation of the research design Borg and Gall (2003) adapted from the 10 steps to 7 steps are modified with the design development phase Gravemeijer (in Wutsqo, 2010). These stages are described as follows.

On Preparation Phase

During the preparation stage research activities, first do the orientation (initial data collection) related to the development of student vocabulary worksheet- 
based additive. After that, the researchers conducted planning activities is to choose classes that will serve as a research subject and determine the design of the forms of student vocabulary worksheet. After the draft form of student vocabulary worksheet has been set then the next step is to make the student vocabulary worksheet initial product.

Thought experiment stage (Thought Experiment)

There are two phases in the experimental stage of thinking that an investigation phase and the beginning of the design phase. In the initial investigation phase, researchers conducted an analysis of the curriculum, student characteristics, and components that would be material affixes worksheet.

In the design phase of preparing student researchers vocabulary worksheet, and the instruments of learning outcomes that refer to aspects that have been identified in the preliminary investigation phase. This phase resulted in a prototype 1 student input vocabulary worksheet. With the conclusion of the prototype 1 , experts will perform validation. In the validation process, experts will look at aspects of the fit between student vocabulary worksheet with a description of the instruments of learning outcomes. Validation will also assess the practicality aspect (practically) student vocabulary worksheet used in the practice of teaching and effectiveness in the aspect of student mastery of vocabulary.

Results of the validation of the prototype one vocabulary worksheet and instruments student learning outcomes will indicate the two possible valid or invalid. If the prototype 1 categorized as invalid, then the validity results require revision or not. If no, this first prototype is ready to be tested or practiced in learning. If there are minor revisions, revisions were made based on feedback or suggestions and the appraiser, nad it then results on prototype 2. Meanwhile, if the prototype 1 and the instruments of student learning outcomes is not valid, a major revision will be done, and revalidation is conducted continually until they are ready to be tested.

\section{Findings on the thought experiment phase}

During the preparation stage, the activities carried out is to conduct orientation (initial data collection) related to the development of student vocabulary worksheet (SVW) based additive. Generally, the material are arranged in the form of an understanding of particle (affixes) that is divided into prefixes (prefixes) and endings (suffixes), inflection (inflection), and word class (part of speech).Once the material is finished is determined, researchers planning. In this activity, researchers determined the class with purposive sampling technique considering a sample class is a class that is in the process of teaching and learning about the material contained affixes and word class. Of a number of existing classes, the class elected Morphology and 
Syntax and Grammar for English Teacher. The second class which is the subject of research.

Furthermore, the researchers determined the forms SVW in the form of a variety of models ranging from the pairing exercise, circling, tables, and stuffing. After the draft form of SVW has been set then the next step is to make the initial SVW product. The result is students feel happy with the model SVW made because in addition they are introduced by forming a word, they are also invited to explore the function of learning vocabulary and use it directly to predict meaning and word class in a text.

\section{Results Experiment Stage Learning}

In this phase of the activities carried out are (a) the initial trials, (b) the initial product improvement, and (c) field trials. On the Early Trial, the students did a pre-test first. The test proposed was in the form of test fields amounts to about 50 questions. The correct answers mean of the pre-test result was 23.9 or $47.9 \%$ of the 50 items. The results of the tests became a validated instrument that will be used for the post test. Of the 50 questions, there were 8 items that were invalid and 42 were valid questions. Of the 42 valid items, it was divided into 10 items whose validity was very low, 14 other were low 14, 13 were moderate, and 5 were high. Based on the validation results, the researchers decided to use only the items with medium and high validity for the post test questions totaling 18 items.

The Initial product improvement.

The initial product design is validated by experts that materials development Hardi Prasetyo, MA, lecturer in English Education, Sanatha Dharma University in Yogyakarta. The description of the results of the validation covers four main points, namely:

Compliance with the material characteristics of the 21st Century English Learners

One of the characteristics of the 21st century learner is to stimulate curiosity (curiousity) by growing curiosity, stimulate critical berpiir, and encourage to seek further information. However, in the production of the first SVW, the three points are still considered quite. It would be better if it propagated a form of exercise that leads to a curiosity issues.

The instruction in the worksheet

Validation of the results obtained that the instruction execution problems tend to be less obvious if used as a form of exercise independently. Class teacher / instructor should further clarify the intent instruction matter. For example Match command options in the left to the right coloumn to be more specific how to set her up. Validator advised to use the word Draw a 
line, or Put the letters in the left coloumn into the numbers in the right ones. While other forms of instruction are also given input is the number of pronouns and The reference that is not specific. For example on training on the use of suffixes to derivation, clause adjectives that you have found in the previous text is less precise. Her text reference should be made clear in practice where.

The layout

There are four things that need to be observed, that the consistency of the font, the color selection, naming / numbering exercise, and image selection. In some SVW, the input obtained, among others:

a. the font type and font size are not the same in each exercise

b. what is the purpose of this picture?

c. The picture is very small for the students to read

d. Naming of the practice does not follow the same format or type. Please compare practice 2 here and practice in the following 3.

The Field Trial

After the initial product in the validation, the SVW tested in class Grammar for English Teacher (GET). After that the students get SVW material that has been validated as much as two meetings of experts. At the next meeting conducted post tests with questions that have previously been validated and amounted to 18 questions. correct answers mean post test results is $11: 43$ or $57.17 \%$ of the 18 items. In addition to testing question, another research instrument was a questionnaire given to the use of student response SVW. From the results of a questionnaire given to 48 students who took the course morphosyntax, the result is that SVW is considered effective to improve English vocabulary students stated by $36.67 \%$ of the students. Furthermore, there are $34.58 \%$ of the students who think that SVW is very effective to improve the mastery of English vocabulary. Results of the questionnaire stated that SVW most effective form of exercise is the fifth, the contextual understanding of the word class. This is possible because the students also facilitated the activities of counseling so that they actually guided from start to finish a series of SVW.

A total of $0.08 \%$ of the students considered SVW is not effective to improve the mastery of English vocabulary, especially in the SVW 3 of mastery suffix. This is possible because the students are invited to play cards together the whole class. Card game should be simplified for small groups and in a wider space. However, $27.91 \%$ of the students stated that SVW is quite effective to improve the mastery of their English vocabulary. 
Data analysis

The analysis was based on three aspects of SVW, the which are validity, practicality, and effectiveness.

The Validity of SVW

Based on the results of the validation performed by the reviewer, the result is that SVW is already well developed. Of the 25 grains of assessment, there are 25 items that are considered good, and 10 items were considered sufficient. Based on measurements of the highest and lowest values, the validation results obtained with the range of scores 3 so declared invalid.

Coverage of the 10 points of assessment are described enough of the stimulation of critical thinking and communication / interaction in the presentation of the material.

$4 \leq \mathrm{Va}<5=$ very valid

$3 \leq$ Va $<4=$ valid

$2 \leq \mathrm{Va}<3=$ less valid

$1 \leq \mathrm{Va}<2=$ Invalid

$\mathrm{Va}=$ average results of expert assessment of the learning model

Practicality

The recommendations given by the validator and the giver of matter is that in terms of practicality, it is very important to develop a form of exercise that is structured and accompanied the design of activities that can be done by both the learners themselves or by the class teacher who uses SVW.

In addition to visits from expert opinion and providers of materials, practicality is also seen from the results of evaluation of the sheet in the form of feasibility study questions related to the use of SVW. There are ten questions related to the use of SVW in the lecture. Overall, the mean total score was 91.8 or 79.8 of a possible top score of 115 . Therefore, in terms of the practicality of this SVW in the category very well.

\section{Effectiveness}

From the aspect relating to the effectiveness of vocabulary, SVW is said to be effective if there are differences in the average value of the pre-test and post test. The mean jsawaban correct pre test results are 23.9 or $47.9 \%$ of the 50 items, while the post test is $11: 43$ or $57.17 \%$ of the 18 items. Of the average value has shown that the average 23.9 of the 50 questions means the average number of answers of students below 50\%. Meanwhile averages 11:43 of the correct answer 18 questions. This means, the answer is already exceeding half the average total correct answers. Thus in terms of effectiveness, SVW proved ineffective because there are differences in the increase in the percentage of correct answer scores at 9:27\%. In addition, the pre-test among 27 students who attend pre-test none of which is able to 
penetrate both criteria which points 70 . Conversely, the post test contained 10 of the 23 students who could penetrate the value of $72.2-94.4$.

\section{Conclusions}

From the results of research and discussion can be summarized as follow:

1) Based on the assessment validator can be concluded that the aspect of validity has met the criteria development vocabualry student worksheet to learn the material additive that has been prepared to have a very good quality.

2) Based on the recommendation of experts and providers of materials, practicality aspect has fulfilled the minimum criteria with certain notes on 21st century learning.

3) The results of the pre-test and post-test student learning augmentation material by using SVW has met the minimum criteria of improvement.

\section{References}

Nation, P. (2013, december 5). Retrieved june 5, 2014, from docenti.unior.it: http://docenti.unior.it/doc_db/doc_omp_05-12-2013_52a0ad63597d4.pdf

www.ballard-tighe.com. (2011). Retrieved February Friday, 2014, from Ballard\&Tighe: www.ballard-

tighe.com/championweb/redlevel/teachingaffixes.pdf

Nakayama, N. (2008). Effects of Vocabulary Learning Using Affix: Special Focus on Prefix. Retrieved February Friday, 2014, from Maebashi kyoai Gakuen College: www.kyoai.ac.jp/college/ronshuu/no-08/nakayama.pdf

Dradjadlaksana, M. (1997). Expanding Vocabulary Mastery Through Understanding Word Formation Rules. Yogyakarta: USD.

Catherine, A. P. (2012).

Sadiq, N. (2012). Teaching English to Non-English Students Department at Islamic University of Indonesia Through Formula 33: Students' Reflection. Journal of Language and Education , 84-102.

Wren, S. (n.d.). Vocabulary. Retrieved June 12, 2014, from Balancedreading.com: http://www.balancedreading.com/vocabulary.html

Gall, Gall, \& Borg. (2003). Educational Research: An Introduction. USA Pearson Longman . 
Aitchison, J. (2003). Teach Yourself Linguistics. London: Hodder Headline.

Tomlison, B. (1998). Materials Development in Language Teaching. London: Cambridge University Press.

Carstairs-McCharty. (2002). An Introduction to English Morphology: Words and Their Structure. Edinburg University Press.

Wutsqo, D. U. (2010). Pengembangan Student Worksheet Berbahasa Inggris Pada Pelajaran Matematika SMP dengan Pendekatan Konstruktivisme dan Pemecahan Masalah. Yogyakarta: Lembaga Penelitian UNY.

Teaching Affixes. (2011). Retrieved Februari 20, 2014, from Ballard\&Tighe: www.ballard-tighe.com

Atmini Dhoruri, R. A. (2009). Pengembangan Student Worksheet Berbasis Matematika Realistik untuk Pembelajaran Matematika secara Bilingual di Sekolah Menengah Pertama.

Rahayu, P. (2012/2013). Pengembangan Worksheet dengan Pendekatan Guided Inquiry pada Pokok Bahasan Suhu dan Kalor untuk Mengoptimalkan Domain Sains Siswa Kelas X SMA N 11 Purworejo Tahun Pelajaran 2012/2013. Jurnal Radiasi , 78-82.

Sunyono. (2008). Development of Student Worksheet Based on Environment to Sains Materials of Yunior High School in Class VII on Semester I. Proceeding of The 2nd International Seminar of Science Education (pp. 1-12). Bandung: UPI Bandung.

Selfi Dwi Fulandari, A. (2013). Pengembangan Student's Worksheet dengan Pendekatan Kontekstual pada Materi Peluang untuk Siswa SMP kelas IX Bilingual. Malang: FMIPA UM.

Rehulina. (2013). Pengembangan Lembar Kerja Siswa (LKS) Berbasis Inquiry untuk Pembelajaran Biologi SMA kelas XII Semester I. Medan: Program Pascasarjana Unimed.

Susanti, R. (2002). Penguasaan Kosa Kata dan Penguasaan Kosakata Bahasa Inggris. Jurnal Pendidikan Penabur , 87 - 93.

Jj Pikulski, T. S. (2004). Teaching and Developing Vocabulary: Key to Longterm Reading Succes. Litho USA: Houghton Mifflin Reading. 
Ahmad Dahlan Journal of English Studies (ADJES)

Vol. 3, Issue 1, March 2016

Harmer, J. (2001). The Practice of English Language Teaching. Malaysia: Longman.

Sinclair, B. (1986). Materials Design for the Promotion of Learner Autonomy: How explicit is explicit? In J. Renauf, The Lexical Approach in ELT (pp. 149165). New York: Routledge.

Willis, D. (1990). The Lexical Syllabus. London: Collins.

Lewis, M. (1993). Implementing the Lexical Approach. . Hove England: Language Teaching Publications.

Wijana, I. (2010). Berkenalan dengan Lingusitik. Yogyakarta: Asc Press.

O'Grady. (2005). Contemporary Linguistics: An Introduction 5th Edition. New York: Bedford/St.Martin. 